\title{
Emergence of two prion subtypes in ovine PrP transgenic mice infected with human MM2-cortical Creutzfeldt-Jakob disease prions
}

Jérôme Chapuis ${ }^{1 \dagger}$, Mohammed Moudjou ${ }^{1 \dagger}$, Fabienne Reine ${ }^{1 \dagger}$, Laetitia Herzog ${ }^{1 \dagger}$, Emilie Jaumain ${ }^{1}$, Céline Chapuis ${ }^{1}$, Isabelle Quadrio ${ }^{2,3}$, Jacques Boulliat ${ }^{4}$, Armand Perret-Liaudet ${ }^{2,3}$, Michel Dron ${ }^{1}$, Hubert Laude ${ }^{1}$, Human Rezaei ${ }^{1}$ and Vincent Béringue ${ }^{1 *}$

\begin{abstract}
Introduction: Mammalian prions are proteinaceous pathogens responsible for a broad range of fatal neurodegenerative diseases in humans and animals. These diseases can occur spontaneously, such as Creutzfeldt-Jakob disease (CJD) in humans, or be acquired or inherited. Prions are primarily formed of macromolecular assemblies of the disease-associated prion protein $\mathrm{PrP}^{\mathrm{SC}}$, a misfolded isoform of the host-encoded prion protein $\operatorname{PrP}^{\mathrm{C}}$. Within defined host-species, prions can exist as conformational variants or strains. Based on both the MN polymorphism at codon 129 of PrP and the electrophoretic signature of PrPSC in the brain, sporadic CJD is classified in different subtypes, which may encode different strains. A transmission barrier, the mechanism of which remains unknown, limits prion cross-species propagation. To adapt to the new host, prions have the capacity to 'mutate' conformationally, leading to the emergence of a variant with new biological properties. Here, we transmitted experimentally one rare subtype of human CJD, designated cortical MM2 (129 MM with type $2 \mathrm{PrP}^{\mathrm{SC}}$ ), to transgenic mice overexpressing either human or the VRQ allele of ovine PrPC

Results: In marked contrast with the reported absence of transmission to knock-in mice expressing physiological levels of human PrP, this subtype transmitted faithfully to mice overexpressing human PrP, and exhibited unique strain features. Onto the ovine PrP sequence, the cortical MM2 subtype abruptly evolved on second passage, thereby allowing emergence of a pair of strain variants with distinct PrPSc biochemical characteristics and differing tropism for the central and lymphoid tissues. These two strain components exhibited remarkably distinct replicative properties in cell-free amplification assay, allowing the 'physical' cloning of the minor, lymphotropic component, and subsequent isolation in ovine PrP mice and RK13 cells.

Conclusions: Here, we provide in-depth assessment of the transmissibility and evolution of one rare subtype of sporadic CJD upon homologous and heterologous transmission. The notion that the environment or matrix where replication is occurring is key to the selection and preferential amplification of prion substrain components raises new questions on the determinants of prion replication within and between species. These data also further interrogate on the interplay between animal and human prions.
\end{abstract}

Keywords: Prion, CJD, Mutation, Sporadic, Transgenic mice

* Correspondence: vincent.beringue@jouy.inra.fr

${ }^{\dagger}$ Equal contributors

${ }^{1}$ INRA (Institut National de la Recherche Agronomique), UR892, Virologie

Immunologie Moléculaires, F-78350 Jouy-en-Josas, France

Full list of author information is available at the end of the article 


\section{Introduction}

Mammalian prions are proteinaceous pathogens responsible for a broad range of fatal neurodegenerative diseases in humans and animals [20]. Prions are primarily formed of macromolecular assemblies of $\mathrm{PrP}^{\mathrm{Sc}}$, a misfolded, 3 -sheet enriched form of the ubiquitously expressed, plasma membrane-anchored, variably $\mathrm{N}$-glycosylated and $\alpha$-helix rich, host-encoded prion protein $\operatorname{PrP}^{\mathrm{C}}$ [49]. This change is based on the self-sustained transfer of a structural information from the $\operatorname{PrP}^{\mathrm{Sc}}$ conformer in the prion state to $\operatorname{PrP}^{\mathrm{C}}$, presumably through a seeding-polymerization process [19]. Within defined host species, $\mathrm{PrP}^{\mathrm{C}}$ can transconform in multiple prion variants or strains, differing in their $\operatorname{PrP}^{\mathrm{Sc}}$ conformations at the level of the tertiary and/or quaternary structure, in their biological properties and in their relative capacity to replicate in cell lines or tissues [5, 8, 14, 21, 37]. Prions can propagate within and between species, as exemplified by the emergence of human variant CreutzfeldtJakob disease (vCJD) through dietary exposure to prions responsible for the bovine spongiform encephalopathy (BSE) epidemics in cattle [62]. Within defined species, prions can also form sporadically. In humans, the incidence of sporadic Creutzfeldt-Jakob disease (sCJD) ranges between 1 and 2 cases per million and per year, and affects mainly elderly people [62]. Atypical BSEs (L-type and Htype) and atypical scrapie Nor98 are thought to develop spontaneously in aged ruminants [8].

Characterizing $\operatorname{PrP}^{\mathrm{Sc}}$ electrophoretic pattern following limited digestion with proteinase $\mathrm{K}(\mathrm{PK})$ can allow differentiation of prion strains. For sCJD, methionine/valine (M/V) polymorphism at codon 129 of the gene encoding $\operatorname{PrP}$ and the migration pattern and relative glycoform abundance of PK-resistant $\operatorname{PrP}^{\mathrm{Sc}}\left(\mathrm{PrP}^{\mathrm{res}}\right)$ allow the definition of different molecular subtypes [28, 45, 57]. These subtypes exhibit specific clinical and neuropathological features [28, 45]. The most common form of SCJD is associated with the presence of type 1 (T1) $\mathrm{PrP}^{\mathrm{res}}$ and homozygosity for methionine at codon 129. The unglycosylated band of $\mathrm{T} 1 \mathrm{PrP}^{\text {res }}$ migrates at $21 \mathrm{kDa}$ in SDS-PAGE gels, and monoglycosylated forms predominate over diglycosylated ones. Rare forms of MM sporadic CJD with a Type 2 (T2) $\mathrm{PrP}^{\text {res }}$ type, - the unglycosylated form of which migrating at $19 \mathrm{kDa}$-, have been diagnosed. These forms are further subclassified as cortical and thalamic variants $[40,45,51]$. The cortical variant is distinguished from all other sporadic forms by the absence of experimental transmission to knock-in mouse models expressing human PrP at physiological levels [10, 30, 40].

Mice transgenic for PrP have been instrumental in deciphering prion strain diversity and in modeling experimentally the so-called species or transmission barrier that limits prions interspecies transmission (for review [8]). In essence, such mice are generated to express specific sequences from mammalian $\mathrm{PrP}^{\mathrm{C}}$ on a mouse PrP-ablated background, and are inoculated with prions. Analyzing the clinical outcome, attack rate and the presence of $\mathrm{PrP}^{\mathrm{Sc}}$ in brain and peripheral tissues where prion replication can occur $[5,27]$ allows the establishment of whether cross-interactions between host $\operatorname{PrP}^{\mathrm{C}}$ and invading $\operatorname{PrP}^{\mathrm{Sc}}$ structural landscapes are possible with regard to prion conversion. The conformational hypothesis $[21,60]$ posits that $\operatorname{PrP}^{C}$ can adopt a limited portfolio of conformations in the $\operatorname{PrP}^{\mathrm{Sc}}$ state, due to structural constraints in its amino acid backbone. If the infecting $\operatorname{PrP}^{\mathrm{Sc}}$ conformation(s) is within the portfolio of possible conformations, cross-species transmission will occur. If not, the transmission barrier will be high, and can lead to an abrupt change in prion strain biological properties $[2,4$, $5,9,13,29,38,46,47,54]$, a phenomenon referred to as a 'mutation'. Whether the newly emerging strain is selected from an ensemble of pre-existing $\mathrm{PrP}^{\mathrm{Sc}}$ conformations in the original inoculum ('quasi-species') or is generated ex abrupto remains difficult to determine. A high transmission barrier does not lead systematically to prion strain 'mutation', as highlighted by the remarkable ability of classical BSE prions to retain their biological properties, despite intermediate passage to a range of different hosts $[12,15,35]$.

Here, we studied the strain biological properties of one rare subtype of sporadic CJD prions, the cortical MM2form, upon transmission to either human or ovine $\operatorname{PrP}$ transgenic mice.

\section{Materials and methods}

\section{Ethics statement}

All animal experiments were approved by the Local Ethics Committee of the authors' institution (Comethea; permit number 12/034). Human tissues samples were selected from the tissue bank of the French National Neuropathology Network for CJD on the basis of the availability of autopsy-retained frozen brain material and informed consent from patient's relatives for autopsy and research use, according to the French regulation (L.1232-1 to L.1232-3, Code de la Santé Publique).

\section{Transgenic mouse lines}

The human PrP tg650 and ovine PrP tg338 lines have been described previously [5, 7, 34]. These lines are homozygous with approximately 6-fold and 8-fold overexpression of human $\operatorname{PrP}^{\mathrm{C}}\left(\mathrm{M}_{129}\right.$ allele) and ovine $\operatorname{PrP}^{\mathrm{C}}$ $\left(\mathrm{V}_{136} \mathrm{R}_{154} \mathrm{Q}_{171}\right.$ allele) in brain, respectively.

\section{MM2-sCJD transmission and titration}

To avoid any cross-contamination, a strict protocol based on the use of disposable equipment and preparation of all inocula in a class II microbiological cabinet was followed. A cerebellum extract was used as source of sporadic CJD, cortical MM2 subtype. This sample has a T2 specific $\mathrm{PrP}^{\mathrm{res}}$ molecular profile. The tissue extract was prepared as $10 \% \mathrm{w} / \mathrm{v}$ homogenate in $5 \% \mathrm{w} / \mathrm{v}$ glucose with a 
Precellys (Ozyme, Montigny-le-Bretonneux, France) for inoculation into tg650 and tg338 mice. Twenty microliters were inoculated intracerebrally in the right hemisphere to groups of individually identified 6-8 week-old tg650 or $\operatorname{tg} 338$ mice, at the level of the parietal cortex. The first mouse succumbing with disease was used for subpassaging. The brain and spleen (when specified) of this mouse were collected with distinct, disposable tools, homogenized at $20 \% \mathrm{w} / \mathrm{v}$ in $5 \%$ glucose and reinoculated intracerebrally at $10 \% \mathrm{w} / \mathrm{v}$.

For endpoint titration, starting from $10 \% \mathrm{w} / \mathrm{v}$ brain homogenate ('undiluted' material), serial 10-fold dilutions of brain homogenates were prepared in $5 \% \mathrm{w} / \mathrm{v}$ glucose containing $5 \% \mathrm{w} / \mathrm{v}$ bovine serum albumin. Twenty microliters of each dilution were immediately inoculated into individually identified 6-8-week-old tg650 or tg338 recipient mice by intracerebral route. Animals were supervised daily for the appearance of neurological signs associated with the development of a prion disease. Animals at terminal stage of disease or at end of life were euthanized. The brains and spleens of all animals were analyzed for $\mathrm{PrP}^{\mathrm{res}}$ content. The number of prion-positive mice was used to establish, by the Spearman-Kärber method, the number of prion infectious units per gram of tissue leading to median mouse infection ( $\mathrm{ID}_{50}$ per gram).

\section{Protein misfolding cyclic amplification (PMCA)}

Mouse brain lysates from healthy tg338 mice were used as the substrate for tg650-passaged MM2-sCJD and tg338adapted MM2-sCJD prion seeds. One round of PMCA, except indicated otherwise, was performed as previously described [41], in a microplate format, on a Q700 sonicator (Delta Labo, Colombelles, France), consisting in 96 cycles of $30 \mathrm{~s}$ of sonication at 200- to $220-\mathrm{W}$ power followed by $29 \mathrm{~min} 30 \mathrm{~s}$ of incubation at $37^{\circ} \mathrm{C}$.

\section{Cell culture}

RK13 cells and the Rov P2FJ6 clone expressing constitutively the VRQ allele of ovine PrP (tg2 construct; [59]) were routinely cultured in Opti-MEM, derived of the Eagle's minimal essential medium (opti-MEM; Gibco), supplemented with $10 \%$ fetal calf serum and antibiotics (penicillin, streptomycin), as previously described [23]. Cells were cultured at $37^{\circ} \mathrm{C}$ in a humidified $5 \% \mathrm{CO}_{2}$ atmosphere in a cell culture incubator. Cell monolayers in 12-well plate were exposed to brain or spleen homogenates from $\operatorname{tg} 338$ mice infected with ovine MM2-sCJD prions diluted in opti-MEM. Cells were exposed to $20 \mu \mathrm{l}$ of $20 \%$ brain homogenate or $40 \mu \mathrm{l}$ of $10 \%$ spleen homogenate diluted in $1 \mathrm{ml}$ of fresh medium. One week later, cells were transferred to one $25-\mathrm{cm} 2$ flask for growing. Each week (i.e. one passage), the cells were then split at the $1 / 4$ dilution in two flasks, one for further cultivation, one for $\mathrm{PrP}^{\mathrm{res}}$ content analysis, as previously described
[58]. Dissociation of the cells was made with a celldissociating buffer (Sigma).

\section{Immunoblot analyses}

$\mathrm{PrP}^{\mathrm{res}}$ was extracted from $20 \%$ (wt/vol.) tissue homogenates with the Bio-Rad TeSeE detection kit, as previously described [4]. Briefly, aliquots were digested with proteinase $\mathrm{K}\left(200 \mu \mathrm{g} / \mathrm{ml}\right.$ final concentration) for $10 \mathrm{~min}$ at $37^{\circ} \mathrm{C}$ before $\mathrm{B}$ buffer precipitation and centrifugation at $28,000 \times \mathrm{g}$ for $15 \mathrm{~min}$. Pellets were resuspended in sample buffer, denatured, run on $12 \%$ Bis/Tris gels (Bio-Rad), electrotransferred onto nitrocellulose membranes, and probed with $0.1 \mu \mathrm{g} / \mathrm{ml}$ biotinylated anti-PrP monoclonal antibody Sha31 antibody (human PrP epitope 145-152, [24]) or with $0.1 \mu \mathrm{g} / \mathrm{ml}$ anti-PrP $12 \mathrm{~B} 2$ antibody (human PrP epitope 89-93, epitope, [33]) and followed by streptavidin conjugated to horseradish peroxidase (HRP) or by HRP conjugated to goat anti-mouse IgG1 antibody $(1 / 20$ 000 final dilution), respectively. Immunoreactivity was visualized by chemiluminescence (GE Healthcare). The size and relative amounts of $\mathrm{PrP}^{\mathrm{res}}$ glycoforms were determined by the use of GeneTools software after acquisition of chemiluminescent signals with a GeneGnome digital imager (Syngene, Frederick, MD).

Enzymatic deglycosylation was performed on denatured $\mathrm{PrP}^{\text {res }}$ with 1,000 $\mathrm{U}$ of recombinant PNGase (New England BioLabs, Evry, France) for $2 \mathrm{~h}$ at $37{ }^{\circ} \mathrm{C}$ in $1 \%$ Nonidet P40 and the proprietary buffer. The deglycosylated proteins were then precipitated with three volumes of cold acetone and resuspended in Laemmli sample buffer for western blot analysis as described above.

\section{Histoblot analyses}

Brains were rapidly removed from euthanized mice and frozen on dry ice. Cryosections were cut at 8-10 $\mu \mathrm{m}$, transferred onto Superfrost slides and kept at $-20{ }^{\circ} \mathrm{C}$ until use. Histoblot analyses were performed as described [36], using the 12F10 anti-PrP antibody (human PrP epitope 142-160, [31]). Analysis was performed with a digital camera (Coolsnap, Photometrics) mounted on a binocular glass (SZX12, Olympus). The sections presented are representative of the analysis of three brains samples.

\section{Results \\ Description of the MM2-sCJD case}

The MM2-sCJD brain source used in the study is a cortical variant, with a rapid clinical evolution. At the age of 62 , the patient, who had comorbidities of diabetes, arterial hypertension and coronopathy, started to complain of memory loss and gait instability. He was admitted at the hospital, and neurological examination demonstrated dysphonia, cerebellar ataxia, confusion and cognitive impairment. The clinical picture rapidly worsened; 4 
months later, he had dramatic cognitive impairment indicative of dementia and many falls backwards. MRI revealed unspecific leucopathy and one hypersignal in the right sylvian area. One month later, the patient was addressed to the emergency Unit for left hemiparesis, mutism and oppositional hypertonia. CSF analysis was positive for 14.3.3 protein. The EEG was negative. There was no pyramidal syndrome. There were myoclonia of the face. The situation evolved to absolute mutism and clonia of the face and of the left superior member. The EGG became periodic. The patient died 6 months after the onset of symptoms. There was no mutation in the PRNP gene. The patient was homozygous for methionine at PrP codon 129. At the autopsy, using the 3F4 anti prion antibody, $\operatorname{PrP}^{\mathrm{Sc}}$ was detected in the cerebellum, in the striatum and in the frontal cortex by western-blot and immunohistochemistry. PrP ${ }^{\text {res }}$ exhibited a T2 electrophoretic pattern in each of these 3 cerebral areas, with predominance of monoglycosylated species and migration of the unglysosylated form at 19 $\mathrm{kDa}$. This pattern was distinct from that characteristic of MM1-sCJD or vCJD (Fig. 1a).

\section{Faithful propagation and unique strain properties of MM2-cortical sCJD prions in human PrP mice}

MM2-sCJD prions were inoculated intracerebrally to transgenic mice expressing the Met $_{129}$ allele of human $\operatorname{PrP}(\operatorname{tg} 650$ line [7]). All the inoculated mice succumbed with typical clinical signs of prion disease, with a mean incubation time of approximately 280 days. Four serial passaging, - including with cloned material -, produced no major change of the incubation time (Table 1).

After each passage, the nervous and lymphoid tissues of the diseased mice were examined for the presence of $\operatorname{PrP}^{\text {res }}$, by immunoblotting. $\operatorname{Pr}^{\text {res }}$ was readily detected in the brains of all the mice analyzed. A typical T2 banding pattern, characterized by aglycosyl $\operatorname{PrP}^{\mathrm{res}}$ migrating at 19 $\mathrm{kDa}$ and prominent monoglycoform species was observed (Fig. 1a-b), as in the human MM2-cortical case. This signature was conserved on subsequent passage and differed from that observed after transmission of the other sCJD subtypes to tg650 mice, as shown for comparison. Those elicited accumulation of $\operatorname{PrP}^{\text {res }}$ with a $\mathrm{T} 1$ signature alone (MM1) or concomitant with the presence of low-size fragments in variable amounts (MV1, VV1, VV2, MV2, Fig. 1a-d; Additional file 1: Figure S1). Only serial transmission of L-type BSE prions to tg650 mice produced a T2 signature in the brain (shown as T2 control in Fig. 1c, $[4,6])$.

A number of $\operatorname{PrP}^{\text {res }}$ typing studies revealed the coexistence of $\mathrm{T} 1$ and $\mathrm{T} 2 \mathrm{PrP}^{\mathrm{res}}$ in the brain of a variable percentage of sCJD cases $[16,48,53,57]$. Analysis of $\mathrm{PrP}^{\mathrm{res}}$ pattern in the brain of MM2-sCJD inoculated tg650 mice, either by using the $12 \mathrm{~B} 2$ anti-PrP antibody that specifically recognizes $\mathrm{T} 1 \mathrm{PrP}^{\mathrm{res}}$ or after deglycosylation failed to detect the T1 isoform (Fig. 1c-d).

$\operatorname{PrP}^{\text {res }}$ was not detectable in the spleens of $\operatorname{tg} 650$ mice inoculated with MM2-sCJD prions (Fig. 1a, $\mathrm{n}=15$ analyzed), at variance with vCJD (Fig. 1a and [7]).

Assessment of the neuroanatomical distribution of $\operatorname{PrP}^{\text {res }}$ by histoblotting revealed that MM2-sCJD prions deposited in the dorsal and habenular thalamic nuclei, in the optic tract, in the cingulum, in the external capsule, in the lateral hypothalamic area and in the trigeminal nuclei of tg650 brain (Fig. 1e).

After three passages in tg650 mice, MM2-sCJD prions were cloned by end-point dilution, as classically done [50], by inoculating serial 10 -fold dilutions of infected brain material at terminal stage of disease to a cohort of tg650 mice. Based on clinical signs and presence of $\mathrm{PrP}^{\mathrm{res}}$ in the brain, a $100 \%$ attack rate was observed until the $10^{-4}$ dilution. The limiting dilution established at $10^{-6}$ (Table 2). Applying the Spearman-Kärber method to the number of animals positive at each dilution provided a provisional infectious titer of $10^{8.1}$ intracerebral tg650 mouse $\mathrm{ID}_{50} \mathrm{U} /$ g brain ( $\mathrm{ID}_{50} \mathrm{IC}$ in $\operatorname{tg} 650 / \mathrm{g}$ ), a value 50 to 100 -fold lower than that calculated for MM1-sCJD and vCJD, respectively $[7,26]$.

Collectively, these results indicate that cortical MM2sCJD prions propagated with no transmission barrier in human $\operatorname{PrP} \operatorname{tg} 650$ mice. The biological strain phenotype observed in these mice was unique amongst the other sCJD or vCJD sources transmitted so far.

\section{Isolation of 2 prion strain types with preferential tissue tropism on serial transmission of MM2-sCJD to ovine PrP mice}

The same human source of MM2-sCJD was serially transmitted by intracerebral route to mice expressing the VRQ allele of ovine PrP ( $\operatorname{tg} 338$ line; [34]), so as to assess both the cross-species transmission capacity of MM2-sCJD prions and the convertibility of ovine $\mathrm{PrP}^{\mathrm{VRQ}}$ by foreign prions. On primary passage, six out of the seven inoculated mice developed a neurologic disease, with a mean incubation time of $557 \pm 11$ days, suggesting that propagation onto the ovine PrP sequence has occurred readily. On second passage, the mean incubation was dramatically shortened to approximately 80 days, a value that remained stable over 4 subpassages (Table 1). This abrupt change in the incubation time between the $1^{\text {st }}$ and the $2^{\text {nd }}$ passage is consistent with the isolation of a shorter incubation period variant $[2,4,5$, $8,9,13,29,46,47,54]$.

$\operatorname{PrP}^{\text {res }}$ was detected by western blot in the brains of all diseased mice. A single banding pattern was observed on primary and subsequent passage. This pattern was designated $\mathrm{T}^{\mathrm{Ov}}$, as it resembled that of MM2-sCJD 

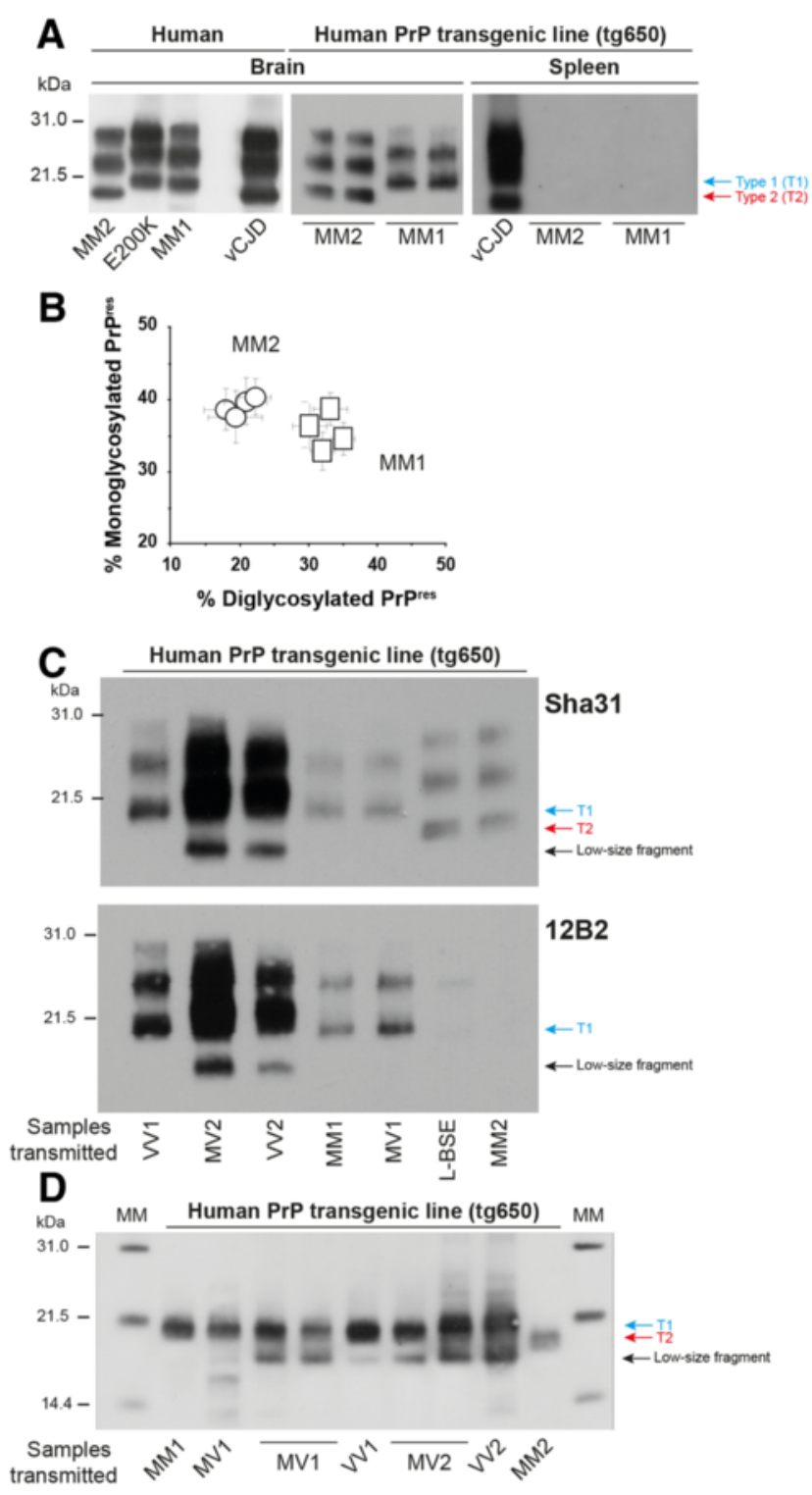

E

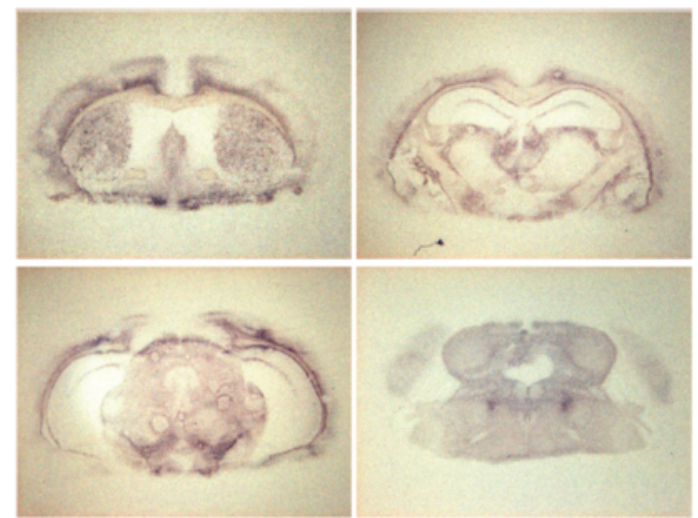

Fig. 1 (See legend on next page.) 
(See figure on previous page.)

Fig. 1 Biochemical and histopathological strain phenotype of MM2-sCJD prions in human PrP mice. (a) Electrophoretic pattern of cortical MM2SCJD prions in human brain and in human PrP mouse (tg650) brains and spleens. Tissue homogenates were subjected to western blot analyses after limited proteinase K digestion. Blots were probed with Sha31 antibody. Other human prion sources (MM1-sCJD, E200K familial CJD and variant CJD) are shown as controls. The equivalent of 0.5 and $2 \mathrm{mg}$ of brain and spleen tissue was loaded on the SDS-PAGE gel. Red and blue arrows denote the unglysosylated bands of PrPres migrating at $21 \mathrm{kDa}(\mathrm{T} 1)$ and $19 \mathrm{kDa}(\mathrm{T} 2)$, respectively. Molecular masses (MM) of protein standards are indicated in kilodaltons. (b) Ratio of diglycosylated and monoglycosylated PrPres species in the brains of tg650 mice following serial transmission (4 passages) of MM2-SCJD (circles) and MM1-sCJD (squares) prions (data plotted as means \pm SEM, $\mathrm{n}=6$ mice analyzed at each passage). (c) Western blot analysis of $\mathrm{PrP}^{\text {res }}$ in the brain of tg650 mice infected with MM2-sCJD prions, after blotting with Sha31 antibody (top) or $12 \mathrm{~B} 2$ antibody specific for Type 1 PrPres (bottom). The banding patterns observed on transmission of other CJD subtypes and atypical L-BSE (which exhibits also a T2 signature, [4]) are shown for comparison. The equivalent of $1 \mathrm{mg}$ (Sha31) and $7 \mathrm{mg}$ (12B12) tissue were run on the SDS-PAGE gels for MM2-sCJD and L-BSE infected brains. The equivalent of $1 \mathrm{mg}$ (Sha31, W1, MM1, MV1; 12B2, MV2, W2), 0.5 mg (Sha31 MV2, W2), 2 mg (12B2, W1, MM1, MV1) were loaded for the other samples. Note the presence of low-size PrPres fragments in the brain of tg650 mice infected with MV2 and W2 sCJD sources (black arrow). (d) Western blot analysis of PrPres in the brain of tg650 mice infected with MM2-sCJD prions, after deglycosylation by PNGase F. Blots were probed with Sha31. Other CJD subtypes are shown for comparison. The equivalent of $0.2 \mathrm{mg}$ of brain tissue (MM1, MM2), $0.1 \mathrm{mg}(\mathrm{MV} 1, \mathrm{~W} 1)$ and $0.05 \mathrm{mg}$ (MV2, W2) were run on the SDS-PAGE gels. MM: molecular mass standards. (e) Regional distribution of PrPres in the brain of tg650 mice infected with MM2-sCJD prions, by representative histoblots in 4 different antero-posterior sections. See [7] for comparison with transmission of MM1-sCJD prions. Histoblots were probed with 12F10 anti-PrP antibody

before and following passage in tg650 mice with regard to aglycosyl $\mathrm{PrP}^{\mathrm{res}}$ migrating at $\sim 19 \mathrm{kDa}$ (Fig. 2a-b).

Histoblot analyses revealed preferential distribution of $\mathrm{PrP}^{\mathrm{res}}$ in the dorsal and habenular, medial geniculate thalamic nuclei, in the cingulum, in the fasciculus retroflexus, in the external capsule and in the raphe nuclei regions of terminally sick tg338 brains (Fig. 3a).

Spleens from diseased mice gradually accumulate detectable levels of $\operatorname{PrP}^{\text {res }}$ over subpassaging $\left(0 / 5\right.$ at $1^{\text {st }}$ passage; $1 / 2$ on $2^{\text {nd }}$ passage, $5 / 5$ on $3^{\text {rd }}$ and subsequent passages). The spleen-banding pattern was homogeneous and distinct from that observed in the brain, the unglysosylated $\operatorname{PrP}^{\text {res }}$ core migrating at $\sim 21 \mathrm{kDa}$ (Fig. 2a-b). This pattern was denominated $\mathrm{T} 1{ }^{\mathrm{Ov}}$.

MM2-sCJD prions passed twice in tg338 mouse brains $\left(\mathrm{T} 2{ }^{\mathrm{Ov}}\right)$ were biologically cloned by end-point dilution in tg338 mice. Based on clinical signs and presence of $\mathrm{PrP}^{\text {res }}$ in the brain, a $100 \%$ attack rate was observed until the $10^{-5}$ dilution. The limiting dilution established at $10^{-6}$ (Table 2). Applying the Spearman-Kärber method to the number of animals positive at each dilution provided an infectious titer of $10^{8.8} \mathrm{ID}_{50}$ IC in tg338/g. Subpassaging with brain

Table 1 Serial transmission of MM2-cortical SCJD to mice expressing human or ovine PrP

\begin{tabular}{llll}
\hline Inoculum & Passage & Mean incubation time ${ }^{\mathrm{b}}\left(\mathrm{n} / \mathrm{n}_{0}\right)$ \\
\hline \multirow{3}{*}{ MM2-sCJD } & 1 & $\operatorname{tg} 650$ (human PrP) & $\operatorname{tg} 338$ (ovine PrP) \\
& 2 & $278 \pm 6(6 / 6)$ & $557 \pm 11(6 / 7)$ \\
& 3 & $274 \pm 4(8 / 8)$ & $84 \pm 1(6 / 6)$ \\
& 4 & $268 \pm 4(12 / 12)$ & $81 \pm 2(6 / 6)$ \\
& 5 & nd & $78 \pm 2(7 / 7)$ \\
\hline
\end{tabular}

$\mathrm{n} / \mathrm{n}_{0}$ : number of mice with neurological disease and positive for $\mathrm{PrP}^{\text {res }}$ in the brain by immunoblotting/number of inoculated mice

${ }^{\text {a }}$ Subpassage after cloning by end-point titration

${ }^{b}$ Days $\pm S E$ of the mean.

nd: not done material of a terminally sick mouse inoculated at the limiting dilution induced disease in $79 \pm 2$ days (6/6 mice). While the $\mathrm{T} 2{ }^{\mathrm{Ov}} \mathrm{PrP}^{\mathrm{res}}$ pattern was conserved in the brain of these animals, the $\mathrm{T}^{\mathrm{Ov}}$ signature in the spleen was lost; two-third of the spleens analyzed accumulated low levels of $\mathrm{T}^{\mathrm{Ov}} \mathrm{PrP}^{\mathrm{res}}$ and one-third were negative (Fig. $2 \mathrm{~b}$ ). On a further subpassage with brain material, the $\mathrm{T}_{2}{ }^{\mathrm{Ov}} \mathrm{PrP}^{\mathrm{res}}$ signature was observed in the 6 spleens and brains analyzed (Fig. 2b, Table 3). This material was designated tg338cloned MM2-sCJD prions. There was limited variation in the distribution of $\mathrm{PrP}^{\mathrm{res}}$ deposits in the brains of $\operatorname{tg} 338$ mice infected with cloned and uncloned MM2-sCJD material. $\operatorname{Pr} \mathrm{P}^{\text {res }}$ deposition was more and less pronounced in the dorsal thalamic nuclei and in the external capsule/cingulum, respectively (Fig. 3b).

Collectively, these results demonstrate that the serial transmission of MM2-sCJD prions to tg338 mice led, after an abrupt shortening of the incubation time, to the isolation of two strain components, a dominant $\mathrm{T} 2{ }^{\mathrm{Ov}}$ component in the brain and a $\mathrm{T} 1^{\mathrm{Ov}}$ subcomponent that preferentially populates the spleen. Biological cloning of brain material allowed elimination of the $\mathrm{T}^{\mathrm{Ov}}$

Table 2 Endpoint titration of serially passaged MM2-sCJD prions in human or ovine PrP mice

\begin{tabular}{llll}
\hline Inoculum & Dilution & Mean incubation time ${ }^{\mathrm{a}}\left(\mathrm{n} / \mathrm{n}_{0}\right)$ \\
\hline MM2-sCJD $^{\mathrm{b}}$ & & $\operatorname{tg} 650$ (human PrP) & $\operatorname{tg} 338$ (ovine PrP) \\
& $10^{-4}$ & $351 \pm 6(5 / 5)$ & nd \\
& $10^{-5}$ & $441 \pm 51(3 / 5)$ & $163 \pm 10(6 / 6)$ \\
& $10^{-6}$ & $424 ; 501(2 / 6)$ & $227 \pm 22(4 / 6)$ \\
$10^{-7}$ & $>600(0 / 6)$ & $>500(0 / 6)$ \\
& $10^{-8}$ & $>600(0 / 6)$ & $>500(0 / 6)$ \\
\hline
\end{tabular}

$\mathrm{n} / \mathrm{n}_{0}$ : number of mice with neurological disease and positive for $\mathrm{PrP}^{\text {res }}$ in the brain by immunoblotting/number of inoculated mice

${ }^{a}$ Days \pm SE of the mean.

${ }^{\mathrm{b}} \mathrm{MM} 2-\mathrm{sCJD}$ iteratively passaged in either tg650 or tg338 mice. nd: not done 


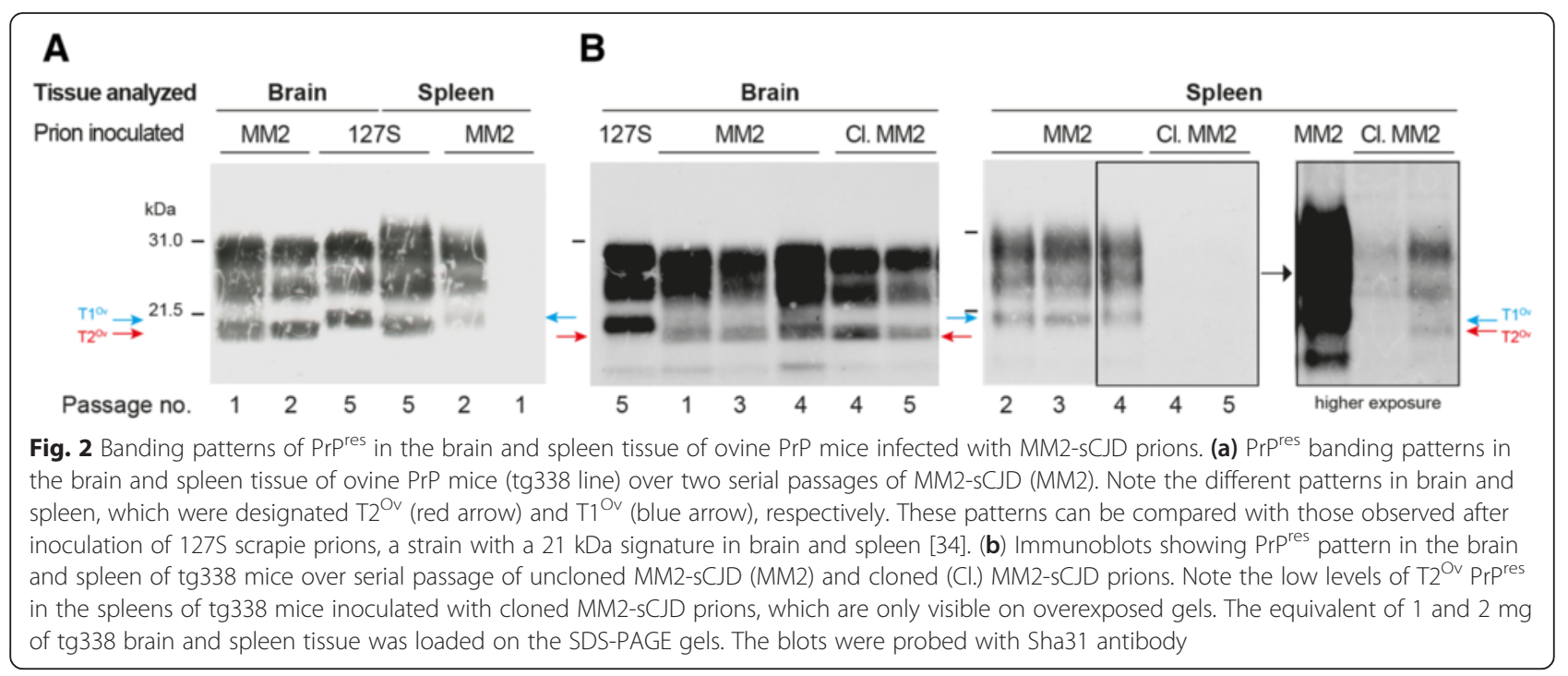

component, at least to levels below detectable replication in tg338 mice.

\section{Preferential selection of the $\mathrm{T}^{\text {Ov }}$ substrain component by protein misfolding cyclic amplification}

Having identified that tg338-adapted, MM2-sCJD prions were a mixture of two components, we next examined whether one would outcompete the other in cell free conversion assays such as PMCA [52]. PMCA allows $\operatorname{PrP}^{\mathrm{Sc}}$ templating the conversion of $\operatorname{PrP}^{\mathrm{C}}$ by repetitive cycles of incubation and sonication, leading to amplification of subinfectious levels of $\operatorname{PrP}^{\mathrm{Sc}}$. Brain homogenates from tg338-passaged MM2-sCJD prions $\left(2^{\text {nd }}\right.$ or $3^{\text {rd }}$ passage; $\mathrm{T} 2{ }^{\mathrm{Ov}}$ signature) were serially diluted up to the $10^{-12}$ dilution and mixed with healthy brain homogenate from $\operatorname{tg} 338$ mice. The resulting mixture was submitted to one round of PMCA reaction, using a highly efficient method previously described [41]. The amplified products were then PK digested and analyzed by Western blot. Detection of $\operatorname{PrP}^{\text {res }}$ was achieved in reaction mixtures seeded with 10 ${ }^{-9}$-diluted brain material ( $\mathrm{n}=6$ independent experiments), suggesting efficient amplification, as previously observed with $127 \mathrm{~S}$ scrapie prions (Fig. 4a, d, [41]). Remarkably, the banding pattern of all amplified products (even after seeding with lowly-diluted brain material) was distinct from that of the inoculum, the unglysosylated $\mathrm{PrP}^{\mathrm{res}}$ core migrating at $\sim 21 \mathrm{kDa}$ (Fig. 4a), thus suggesting that the $\mathrm{T} 1{ }^{\mathrm{Ov}}$ subcomponent was preferentially amplified. PMCA performed with $\mathrm{T} 1^{\mathrm{Ov}}$-enriched $\operatorname{tg} 338$ spleen material (at $3^{\text {rd }}$ passage) further confirmed the efficient amplification of this prion component. The limiting dilution established at $10^{-9}$, as with brain material $(\mathrm{n}=3$ independent experiments) and the $\operatorname{PrP}^{\mathrm{res}}$ profile of the amplicons appeared as $\mathrm{T} 1^{\mathrm{Ov}}$ (Fig. 4b).
To ascertain whether the PMCA process results in the selective amplification of $\mathrm{T} 1{ }^{\mathrm{Ov}}$ prions, $\operatorname{tg} 338$ mice were intracerebrally challenged with products generated from the $10^{-8}$ brain seed, that is 100 -fold below the lowest dose resulting in positive transmission by bioassay (Table 2). Tg338 mice succumbed with disease in $105 \pm 1$ days, a survival time that established to approximately 90 days on further subpassaging (Table 3). A unique $\mathrm{T} 1{ }^{\mathrm{Ov}}$ type electrophoretic signature was observed in both brains and spleens over these two passages, whether subpassage was performed with brain or spleen material (Fig. 4c, Table 3). After inoculation of brain or spleen material, $\operatorname{PrP}^{\text {res }}$ deposition in the brain also differed from that observed with non amplified MM2-sCJD prions. $\operatorname{PrP}^{\mathrm{res}}$ deposited more ventrally in the lateral hypothalamic areas and granular-like deposits were observed in the corpus callosum (Fig. $3 \mathrm{c}-\mathrm{d}$ ). This material was designated PMCA MM2-sCJD prions. Brains infected with PMCA MM2-sCJD prions were also submitted to PMCA reaction. The seeding activity detection limit established at the $10^{-9}$ dilution, as observed with uncloned MM2-sCJD prions passaged in tg338 mice (Fig. 4d).

The use of tg338-cloned MM2-sCJD brain material further demonstrated that $\mathrm{T} 2{ }^{\mathrm{Ov}}$ seeds were poor convertors in PMCA reaction. The limiting dilution achieved was dramatically decreased by $10^{4}$-fold as compared to uncloned MM2-sCJD prions (Fig. 4d). PrP ${ }^{\text {res }}$ banding pattern observed was still $\mathrm{T} 1^{\mathrm{Ov}}$, suggesting that one biological cloning was not sufficient to eliminate totally this subcomponent for PMCA reaction, owing to the improved sensitivity of this technique [41].

Collectively, these data indicated that the $\mathrm{T} 1^{\mathrm{Ov}}$ subtype was an isolable substrain component of MM2-sCJD in $\operatorname{tg} 338$ mice, which carried most if not all the PMCA 


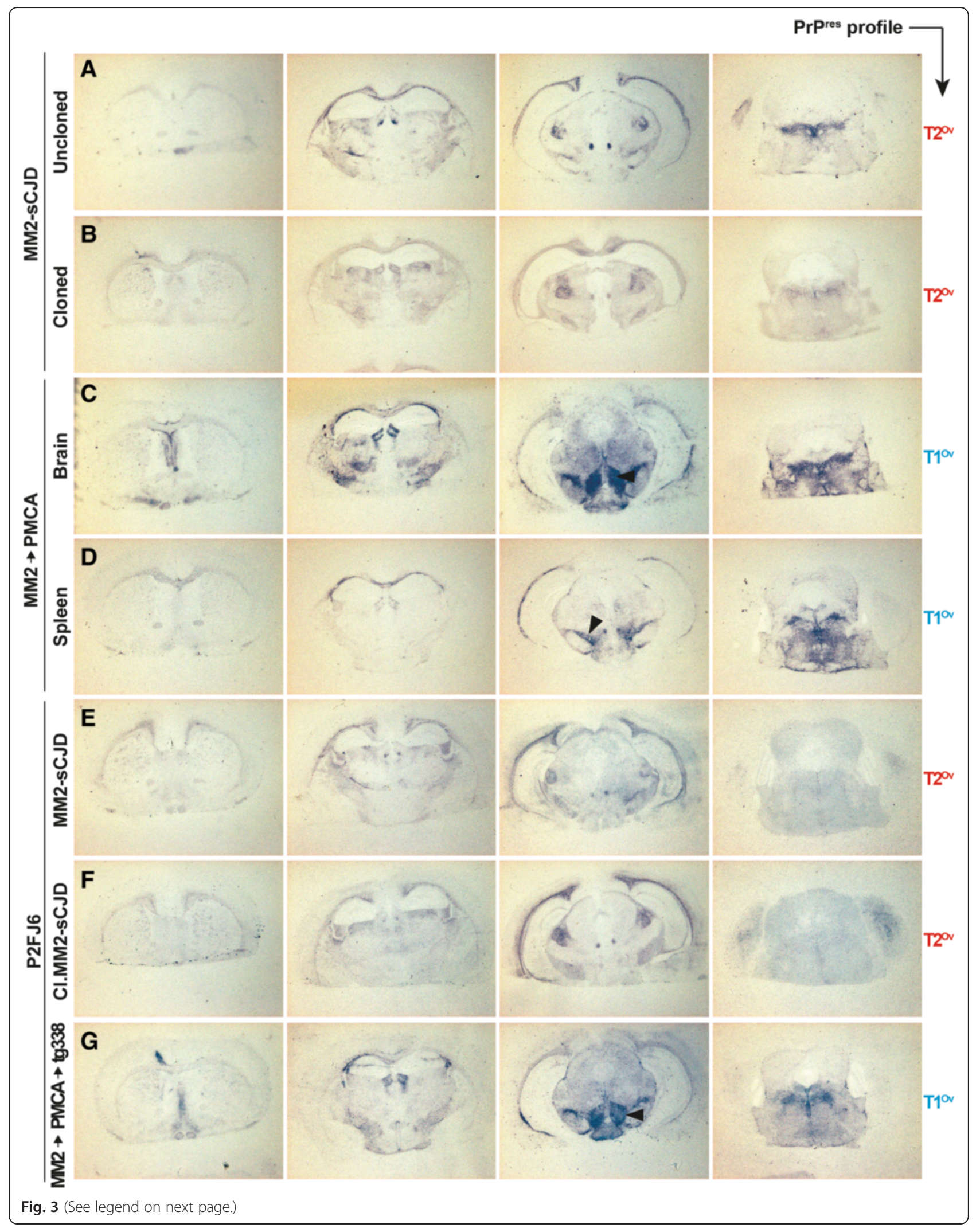


(See figure on previous page.)

Fig. 3 PrPres deposition pattern in the brain of ovine PrP mice challenged with MM2-sCJD prions. Representative histoblots in 4 different antero-posterior sections of tg338 mouse brain after inoculation with tg338-passaged MM2-sCJD prions (a, $4^{\text {th }}$ passage), tg338-cloned MM2-sCJD prions (b), brain (c) and spleen (d) of tg338 mice inoculated with PMCA-amplified MM2-sCJD prions, P2FJ6 cells challenged with uncloned $(\mathbf{e})$, cloned $(\mathbf{f})$ and PMCA-derived $(\mathbf{g})$ MM2-SCJD prions (MM2 $\rightarrow$ PMCA $\rightarrow \operatorname{tg} 338)$. Note the marked deposition of PrPres in the lateral hypothalamic areas of mice inoculated with $\mathrm{T1}^{\mathrm{Ov}}$ prions (black arrowhead). Blots were probed with $12 \mathrm{~F} 10$

activity. Separately, the $\mathrm{T} 1^{\mathrm{Ov}}$ subcomponent was pathogenic in tg338 mice, as $\mathrm{T}_{2}{ }^{\mathrm{Ov}}$.

PMCA-generation of the $\mathrm{T}^{\mathrm{Ov}}$ substrain component by seeding ovine PrPC with human MM2-sCJD prions

PMCA has been shown as a convenient model to investigate experimentally prion species barrier $[3,18,25]$. We thus examined the outcome of confronting directly human MM2-sCJD prions to ovine $\operatorname{PrP}^{C}$. Brain homogenates from uninfected tg338 mice were seeded with a $10^{-3}$ dilution of brain homogenate from tg650 mice infected with uncloned or cloned MM2-sCJD prions. To augment the chance of crossing the species barrier, up to three rounds of PMCA were performed. At each round, the amplified products were analyzed for $\operatorname{PrP}^{\text {res }}$ content by Western blot. As shown in Fig. 4e (representative of $n=4$ independent experiments), $\operatorname{Pr} \mathrm{P}^{\text {res }}$ was detected at each round. The electrophoretic pattern observed resembled $\mathrm{T}^{\mathrm{Ov}}$, the unglysosylated $\mathrm{PrP}^{\mathrm{res}}$ core migrating at $\sim 21 \mathrm{kDa}$. A T2 ${ }^{\mathrm{Ov}}$ $\mathrm{PrP}^{\text {res }}$ signature was occasionally observed in the PMCA

Table 3 Transmission of MM2-sCJD prions to ovine PrP mice after PMCA amplification or passage through P2FJ6 cells

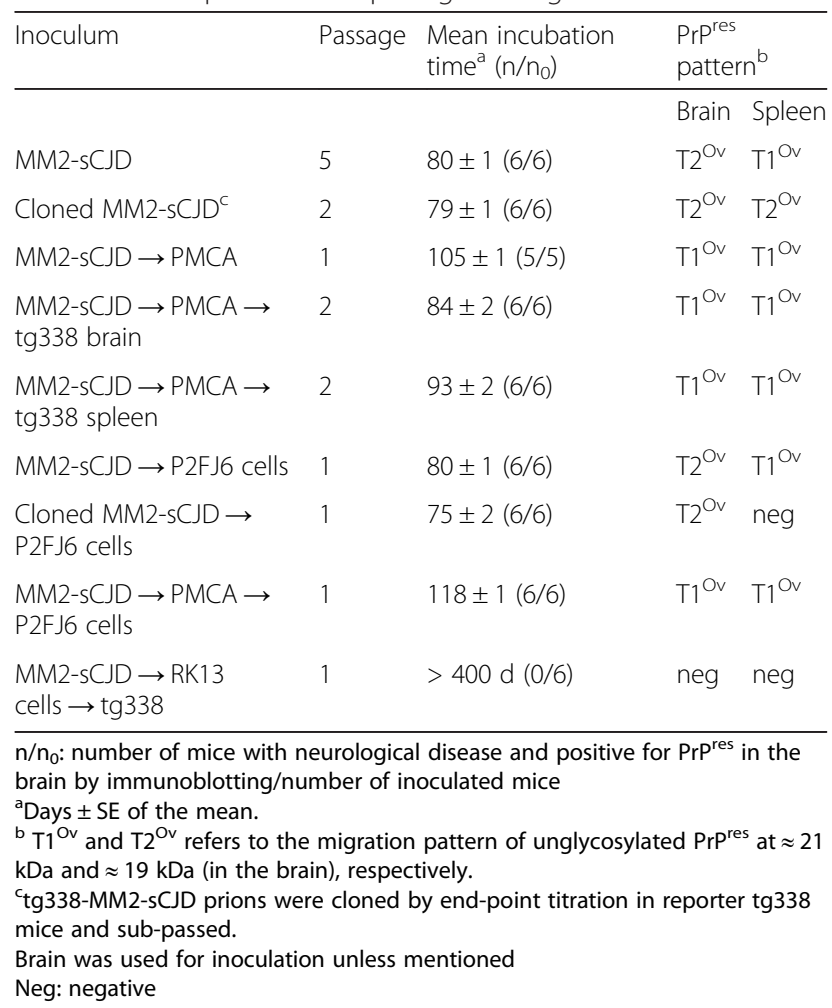

products (1 out of 16 positive reactions, data not shown), suggesting possible stochastic generation of these prions on the ovine PrP sequence. Remarkably, the same efficacy of amplification relative to the number of rounds was found with either cloned or uncloned tg650 material, allowing detection of $\mathrm{T}^{\mathrm{Ov}} \mathrm{PrP}^{\mathrm{res}}$ from $10^{5}$-fold diluted seeds in three rounds (Fig. 4e). It can be extrapolated from these data that under the constraint of having to be amplified by PMCA with an ovine $\operatorname{PrP}$ substrate, $\mathrm{T} 1{ }^{\mathrm{Ov}}$ prions can directly emerge from a human MM2-sCJD prions population, cloned or not.

\section{The two MM2-sCJD ovine subcomponents can be stably passaged in a Rov cell subclone}

RK13 cells expressing the VRQ allele of ovine PrP are permissive to 'fast' scrapie prions, serially passaged or not in $\operatorname{tg} 338$ mice $[32,56,58]$. Motivated by the short incubation times of MM2-sCJD prions in tg338 mice, we examined whether they could propagate in these cells and whether one subcomponent would compete out the other. The Rov9 cell clone [58] and congeners were poorly permissive to tg338-passaged MM2-sCJD prions. Cells mostly failed to accumulate detectable levels of $\operatorname{PrP}^{\text {res }}$, despite exposure to lowly diluted brain homogenate, and prolonged incubation of the cells with the inoculum (data not shown and Munoz-Montesino et al., submitted for publication). Another Rov construct constitutively expressing ovine PrP (P2FJ6 cells) and used routinely in our scrapie cell assays because of its marked susceptibility to scrapie $127 \mathrm{~S}$ prions $([32,56]$ and to be published elsewhere) was permissive to MM2-sCJD prions. To sustain replication, it was necessary to adapt the infection protocol, so as to allow longer time of exposure between the cells and the inoculum (see methods).

Infection of P2FJ6 cells with brain extracts from tg338-adapted MM2-sCJD prions led to detection of $\mathrm{PrP}^{\text {res }}$ from 2 cell passages onwards, as shown by Western blot analyses. The signal increased with passaging and was detected up to 14 passages post-infection, i.e. 14 weeks pi (Fig. 5a). The banding pattern observed was a $\mathrm{T}_{2}{ }^{\mathrm{Ov}}$ pattern with regard to the migration size of unglycosylated $\operatorname{PrP}^{\text {res }}$. The number of passages of MM2sCJD prions onto tg338 mice before infection of the P2FJ6 cells was without influence on the efficacy of the infection, and on the PrP ${ }^{\text {res }}$ electrophoretic pattern (data not shown). $\operatorname{PrP}^{\text {res }}$ could not be detected in the parental 


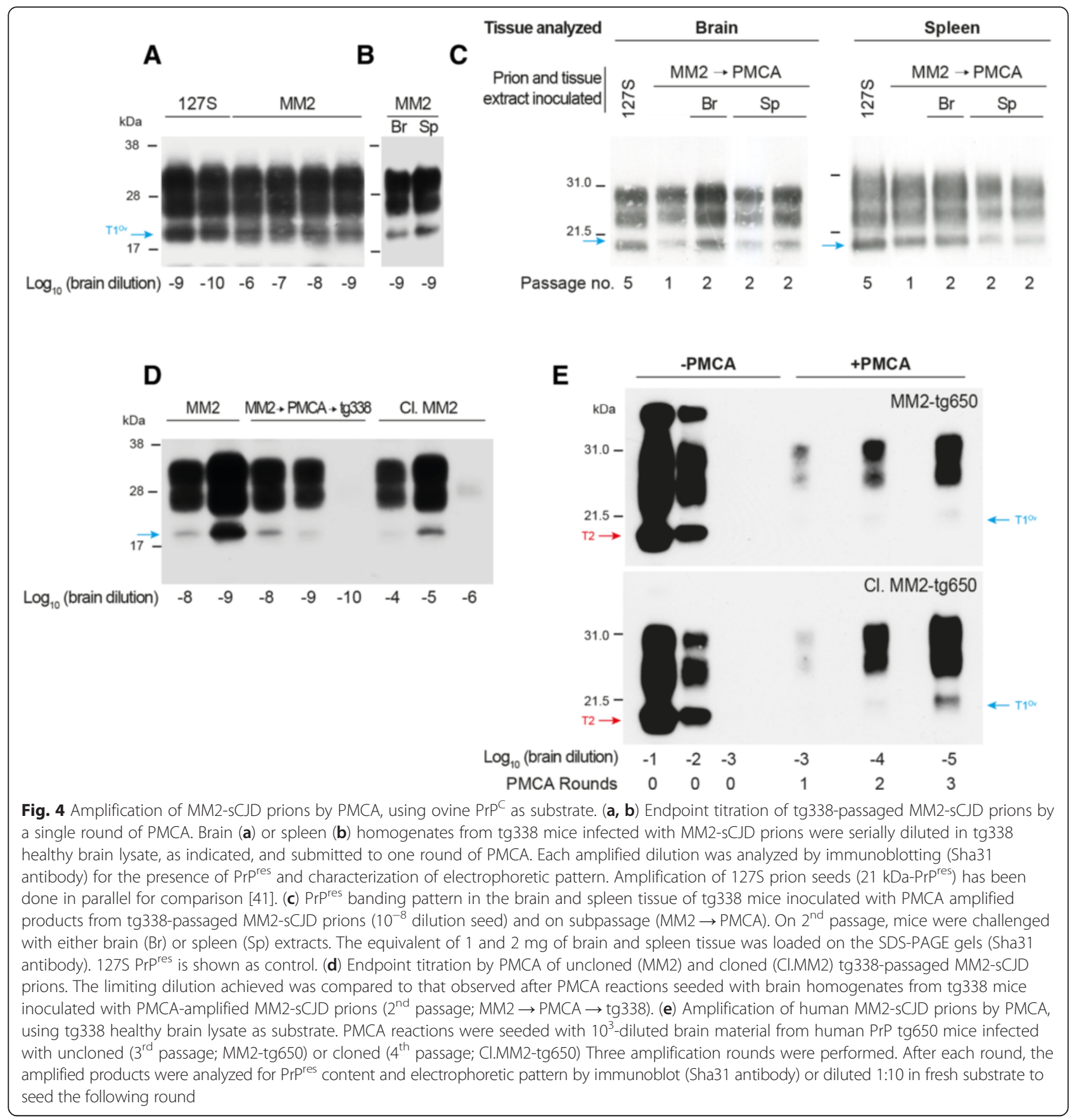

RK13 cell line exposed to tg338-MM2-sCJD prions (Fig. 5a), indicating that the signal observed was not remnant inoculum. Of note, the overall levels of $\operatorname{PrP}^{\text {res }}$ in the P2FJ6 culture were below those observed after infection (at the same dose) with $127 \mathrm{~S}$ scrapie prions (Fig. 5a). Exposing P2FJ6 cells to $\mathrm{T} 1{ }^{\mathrm{Ov}}$-enriched spleens of tg338 mice infected with MM2-sCJD prions led to accumulation of low levels of $\mathrm{PrP}^{\text {res }}$, with a $\mathrm{T} 1^{\mathrm{Ov}}$ banding pattern (Fig. 5b), suggesting that the cells were also permissive to $\mathrm{T} 1{ }^{\mathrm{Ov}}$ prions.
All tg338 mice inoculated with P2FJ6 cell lysates exposed to tg338 brain-passaged MM2-sCJD prions (at passage 7 , to exclude remnant inoculum, as confirmed with RK13 cells) developed disease with a strain phenotype similar to MM2-sCJD prions in tg338 mice: the mean incubation time established at 80 dpi (Table 3); brain $\mathrm{PrP}^{\text {res }}$ exhibited a $\mathrm{T} 2{ }^{\mathrm{Ov}}$ banding pattern (Fig. $5 \mathrm{~d}$ ), and neuroanatomical distribution of $\mathrm{PrP}^{\text {res }}$ closely resembled that observed upon direct MM2-sCJD subpassaging (Fig. 3e). Immunoblot examination of the spleens 


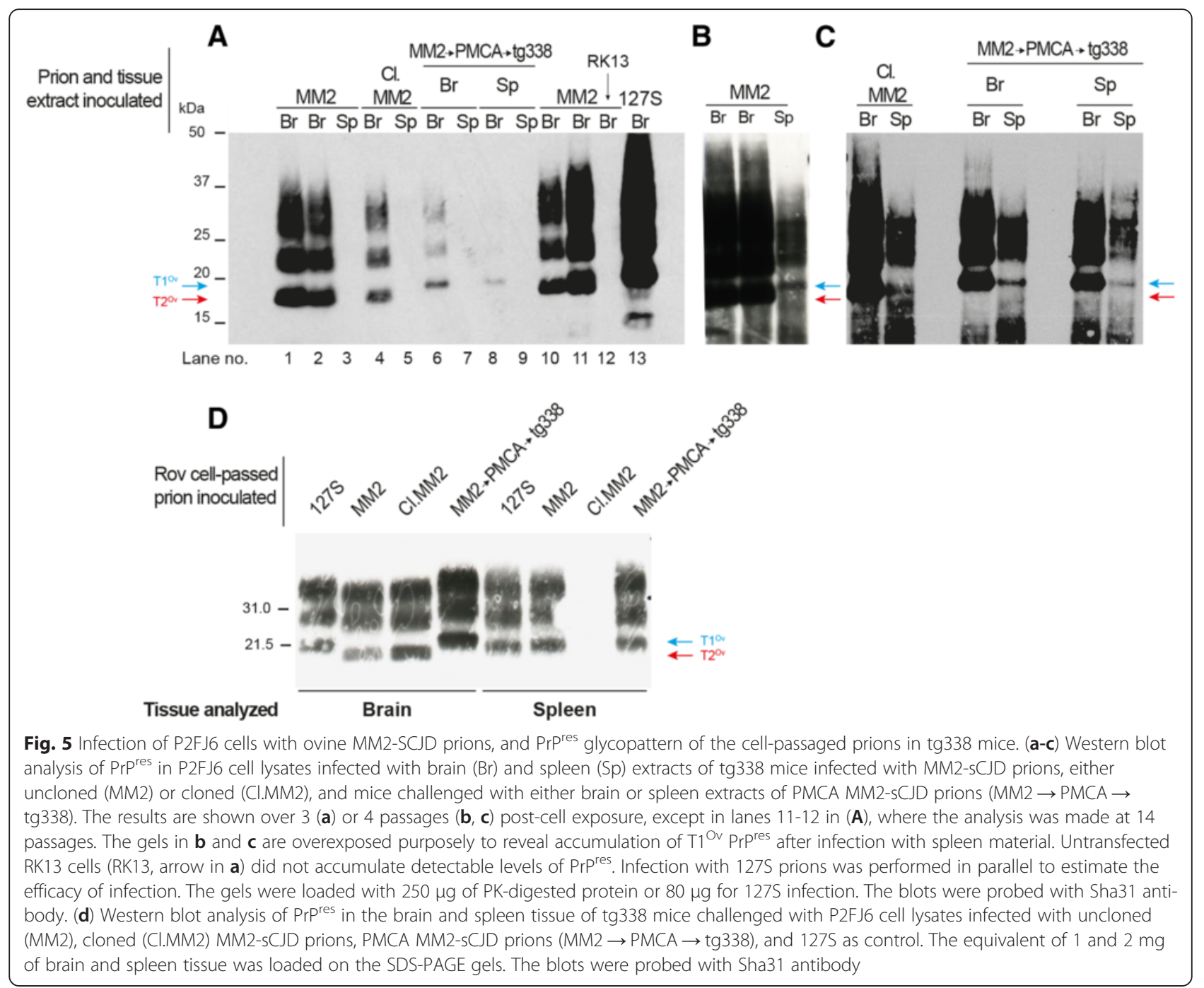

revealed the presence of the $\mathrm{T} 1{ }^{\mathrm{Ov}}$ component (Fig. 5d), suggesting 'silent' propagation in the P2FJ6 cells.

To further ascertain that P2FJ6 cells could propagate $\mathrm{T} 1^{\mathrm{Ov}}$ as $\mathrm{T} 2^{\mathrm{Ov}}$ prions and exclude any in-cell reversal phenomenon between the two components, P2FJ6 cells were exposed to the two $\mathrm{T} 2{ }^{\mathrm{Ov}}$ and $\mathrm{T} 1{ }^{\mathrm{Ov}}$ subcomponents separately, by using brain material derived from tg338cloned MM2-sCJD prions (i.e. enriched in $\mathrm{T} 2{ }^{\mathrm{Ov}}$ ) or from PMCA MM2-sCJD prions (i.e. enriched in $\mathrm{T} 1^{\mathrm{Ov}}$ ), respectively. In that case, cells faithfully accumulated prions with $\mathrm{T} 2{ }^{\mathrm{Ov}}$ and $\mathrm{T}^{\mathrm{Ov}} \mathrm{PrP}^{\mathrm{res}}$ signatures, respectively (Fig. 5a). When cells were challenged with spleen material from the same mice, infection proceeded at slower rate, as shown by the lower levels of $\operatorname{PrP}^{\text {res }}$ accumulation, which necessitated highly exposed gels to be visible (Fig. 5c). The $\mathrm{PrP}^{\text {res }}$ signature observed were $\mathrm{T} 2{ }^{\mathrm{Ov}}$ from cloned material and $\mathrm{T} 1{ }^{\mathrm{Ov}}$ from PMCA passaged material (Fig. $5 \mathrm{c}$ ), as in the spleen. Whatever the tissue used to infect the cells, the $\mathrm{T} 1^{\mathrm{Ov}}$ and $\mathrm{T} 2^{\mathrm{Ov}}$ signatures were kept up to 12 cell passages, suggesting stable cell replication of the two subcomponents independently (data not shown). Reinoculation of the so-called $\mathrm{T} 2{ }^{\mathrm{Ov}}$ and $\mathrm{T} 1{ }^{\mathrm{Ov}}$ cell lysates to tg338 mice confirmed the faithful and separate propagation of the two agents in the cells. Indeed their strain specific signature was preserved after intermediate passage in cells, with regard to incubation time (Table 3 ), $\mathrm{PrP}^{\mathrm{res}}$ banding pattern in brain and spleen tissues (Fig. 5d) and histoblot analyses (Fig. 3f-g). Altogether, these data indicate that Rov P2FJ6 cells were fully competent to replicate the two tg338 passaged MM2-sCJD infectious components.

\section{Discussion}

We report here on the capacity of a rare subtype of human sCJD prions (MM2, cortical variant) to adapt onto the ovine PrP sequence, thereby modifying its apparent substrain composition and tissue tropism. We further show that the isolated variants can exhibit distinct 
replicative or biological behavior depending on the matrix or environment surrounding the prion conversion process.

Human PrP tg650 mice challenged with the MM2cortical CJD subtype developed a clinical disease at full attack rate in less than 300 days. A T2 $\mathrm{PrP}^{\text {res }}$ profile was invariably observed in the inoculated mice. These characteristics were maintained over passaging, suggesting faithful propagation of this agent in this mouse line. Together, the incubation time in tg650 mice and the brain $\mathrm{PrP}^{\text {res }}$ profiles were unique among the panel of CJD cases transmitted so far to the tg650 line (Fig. 1 and unpublished data), thus fully supporting the contention that MM2-cortical CJD is a specific CJD subtype, as previously concluded from the absence of transmission to transgenic lines expressing physiological level of human $\operatorname{PrP}[10,30,40]$. Human PrP overexpression in tg650 mice may have been key in the success of transmission. Additionally, we used a cerebellum extract as inoculum, whereas previously, a cerebral cortex extract was used. Different brains and different brain regions harbor prion infectivity titers that can vary by 100 -fold with regard to the number of infectious units per milligram of tissue $[1,11]$. While such a difference would barely affect the transmission rate of MM2-sCJD prions to tg650 mice (Table 2), this might be an issue in knock-in human PrP transgenic mice in which disease develops at slower pace [10].

While MM2-sCJD prions propagated faithfully in human PrP mice, the outcome was different upon transmission to ovine $\operatorname{PrP} \operatorname{tg} 338$ mice. Efficient transmission occurred on primary passage, at near full attack rate, albeit with a prolonged incubation period. A drastic reduction in the incubation time from 550 to 80 days occurred on secondary passage, consistent with the isolation of a variant, or a 'mutant' by analogy to mutational events observable with conventional microorganisms $[2,4,5,8,9,13,29,46$, $47,54]$. While a $19 \mathrm{~K}$-like $\operatorname{PrP}^{\mathrm{res}}$ signature predominated in tg338 mouse brains as in human or human PrP mouse brain, a second signature, designated $\mathrm{T}^{\mathrm{Ov}}$ gradually emerged with subpassaging in tg338 mouse spleens. This distinct tissue tropism and the possibility to isolate, by conventional biological cloning or cell-free amplification, and further propagate separately and with fidelity the $\mathrm{T} 2{ }^{\mathrm{Ov}}$ and $\mathrm{T} 1{ }^{\mathrm{Ov}}$ types in tg338 mice or P2FJ6 cells indicate that a pair of bona fide prion strains has been isolated on the ovine PrP sequence.

Once propagated alone, we failed to evidence any gradual shift of $\mathrm{T} 2{ }^{\mathrm{OV}}$ towards $\mathrm{T}^{\mathrm{Ov}}$ prions in tg338 mice or in P2FJ6 cells, suggesting that the interspecies prion conversion events have been instrumental in the emergence of the $\mathrm{T} 1{ }^{\mathrm{Ov}}$ substrain component. A recurrent and often perplexing question $[8,21,60,61]$ is whether these agents have been generated de novo on confrontation to the new $\operatorname{PrP}$ sequence or have been preferentially selected from pre-existing $\operatorname{PrP}^{\mathrm{Sc}}$ conformations. Our data support the contention that $\mathrm{T}_{1}{ }^{\mathrm{Ov}}$ prions have been generated de novo: First, if the $\mathrm{T} 1{ }^{\mathrm{Ov}}$ agent preexisted in the human MM2-sCJD source, it was not able to replicate at detectable levels in the spleens of tg650 mice, at variance with other human prion strain sources $[5,6]$. Second, we found no evidence of a T1 signature in the brain of tg650 mice inoculated with MM2-sCJD prions that may putatively be at the origin of $\mathrm{T}^{\mathrm{Ov}}$ prions onto the ovine PrP sequence (Fig. 1). Third, $\mathrm{T}^{\mathrm{Ov}}$ prions could be directly generated by PMCA from the human MM2-SCJD prions population passaged in tg650 mice. The lack of obvious difference in the PMCA efficacy between uncloned and cloned material (Fig. 4e), the latter being theoretically less populated in a potential $\mathrm{T} 1{ }^{\mathrm{Ov}}$ subcomponent (to be compared with the dramatic reduction in the PMCA efficacy when tg338-passaged uncloned and cloned MM2-sCJD prions are amplified, Fig. 4d), suggests de novo generation of $\mathrm{T}^{\mathrm{Ov}}$ on confrontation to the ovine PrP sequence. We acknowledge that definitive proof is lacking and it is possible that substrain heterogeneity may constantly arise even in cloned populations during propagation [39].

Our observations are adding to the view that 2 distinct prion strains can propagate in neural and extraneural tissues of the same host individual [5, 7]. We are currently comparing the retro-transmission properties of the $\mathrm{T}_{1}{ }^{\mathrm{Ov}}$ and $\mathrm{T} 2{ }^{\mathrm{Ov}}$ types to human $\mathrm{PrP}$ mice to examine whether the selection pressure imposed by the heterologous transmission was lower in spleen than brain tissues from tg338 mice, as previously observed [5]. The situation may however be drastically different here, as the $\mathrm{T} 1{ }^{\mathrm{Ov}}$ component emerged gradually in the spleen with subpassaging and adaptation, whereas previously, the spleen component emerged first, and at higher rate, than the brain component [5].

The replicative properties of the two MM2-sCJD ovine prions markedly differed depending on the environment/matrix where ovine PrP conversion occurred: the two components fairly propagated in tg338 mice (yet at variable, tissue-dependent levels) and in P2FJ6 cells, whereas the $\mathrm{T} 1{ }^{\mathrm{Ov}}$ component was selectively amplified by PMCA, despite the use of $\operatorname{tg} 338$ mouse brain as $\operatorname{PrP}^{\mathrm{C}}$ substrate in the PMCA reaction. Comparative (ongoing) titration of isolated $\mathrm{T} 1{ }^{\mathrm{Ov}}$ and $\mathrm{T} 22^{\mathrm{Ov}}$ prions suggest that both agents exhibit similar infectious titers (Table 4). Serial passaging in P2FJ6 cells also indicates that none of the component was outgrowing the other over passaging, suggesting roughly similar half-life and doubling time. Despite the point that our PMCA protocol is relatively promiscuous, allowing efficient amplification of several strains from different species [41], it remains possible that $\mathrm{T}^{\mathrm{Ov}}$ amplification necessitates very specific PMCA conditions. Incidentally, PMCA appears as a 
Table 4 Endpoint titration of isolated $\mathrm{T}_{1}^{\mathrm{Ov}}$ and $\mathrm{T} 2^{\mathrm{Ov}} \mathrm{MM}$-sCJD prions in ovine PrP mice

\begin{tabular}{llll}
\hline Inoculum & Dilution & \multicolumn{2}{l}{ Mean incubation time $^{\mathrm{a}}\left(\mathrm{n} / \mathrm{n}_{0}\right)$} \\
\hline \multirow{2}{*}{ MM2-sCJD } & $10^{-4}$ & $142 \pm 8(5 / 5)$ & $\mathrm{T} 1^{\text {Ovb }}$ \\
& $10^{-5}$ & $146(1 / 6)$ & $\mathrm{nd}$ \\
& $10^{-6}$ & $174 ; 192(2 / 6)^{c}$ & $212 \pm 6(3 / 6)^{c}$ \\
& $10^{-7}$ & $>450(0 / 6)^{c}$ & $>450(0 / 6)^{c}$ \\
& $10^{-8}$ & $>450(0 / 6)^{c}$ & $>450(0 / 6)^{c}$ \\
\hline
\end{tabular}

$\mathrm{n} / \mathrm{n}_{0}$ : number of mice with neurological disease and positive for $\mathrm{PrP}^{\mathrm{res}}$ in the brain by immunoblotting/number of inoculated mice

${ }^{\mathrm{a}}$ Days $\pm \mathrm{SE}$ of the mean.

${ }^{\mathrm{b}} \mathrm{The} \mathrm{T}^{\mathrm{Ov}}$ and $\mathrm{T}_{1}{ }^{\mathrm{Ov}}$ brain material were from tg338-cloned MM2-sCJD prions and from PMCA MM2-sCJD prions, respectively.

congoing experiment

nd: not done

convenient, alternative method to biological cloning, to isolate one prion substrain component from a mixture.

Within the quasi-species concept applied to prions, -which proposes that prions are not constituting a single clone but are embedded with all $\operatorname{PrP}^{\mathrm{Sc}}$ conformational variants [21, 61]-, our observations would suggest that there has been a bottleneck event in tg338 mice (due to the heterologous PrP transmission) which has affected MM2-sCJD prions fitness, at least on primary passage, and has led to the emergence of two strain components. Key to the quasi-species definition is the existence of intra-population interactions, either complementation or interference [44]. Complementation is difficult to accommodate with the observation that there is so far no apparent regeneration of the two $\mathrm{T}^{\mathrm{Ov}}$ and $\mathrm{T} 2{ }^{\mathrm{Ov}}$ subcomponents after intermediate separation of one of the component, either by PMCA or biological cloning. As individuals, both components do not harbor different fitness with regard to incubation time, cell replicability and infectious titer; however, jointly, $\mathrm{T} 2{ }^{\mathrm{Ov}}$ markedly outcompetes $\mathrm{T}^{\mathrm{Ov}}$ in either P2FJ6 cells or in tg338 brain. Neuroanatomically, the absence of replication of $\mathrm{T}^{\mathrm{Ov}}$ prions in certain brain target areas, that are free of $\mathrm{T}_{2}{ }^{\mathrm{Ov}}$ prions (such as the lateral hypothalamic area (Fig. 3)) suggest local interfering mechanisms, independent of competition for the same PrP substrate [55]. We thus propose that the MM2-sCJD 'mutant' isolated in tg338 mice is not a mere agglomeration of independently acting $\mathrm{T} 1{ }^{\mathrm{Ov}}$ and $\mathrm{T} 2{ }^{\mathrm{Ov}}$ conformations.

Since the discovery that RK13 cells expressing the ovine PrP VRQ allele were permissive to certain scrapie prions $[23,58]$, we and others have made numerous attempts to infect these cells or more permissive clones such as the P2FJ6 one with ovine prions sources, passaged or not onto tg338 mice. Most attempts have failed, except for prions classified as 'fast', as based on their short incubation time in reporter tg338 mice (e.g. 127S and LA21K fast, $[42,56])$. Here we show that two other relatively 'fast' agents originating from MM2-sCJD can fairly propagate in Rov cells at their maximum infectivity levels, as assessed by the tg338 bioassay. Many factors can account for the difficulties to replicate prions in immortalized cell lines. Obviously, prion-doubling time must surpass the cell division rate. For 'fast' strains such as $127 \mathrm{~S}$ and LA21K fast, it appears that a subset of small oligomers are by far the most active with respect to prion replication in vivo and to seeding activity by PMCA [32]. This might be key to their sustained ability to replicate in cells. We are currently investigating the oligomeric state of the most active SCJD aggregates. In any case, this extended panel of strains replicating in cell culture opens the possibility to compare their biology in cells expressing wild type or mutated forms of $\operatorname{PrP}$ (Munoz-Montesino et al., submitted for publication).

\section{Conclusions}

We report here that prions associated with a cortical subtype of human MM2-sCJD prions converts the ovine VRQ PrP in its disease-associated form. The same source propagates efficiently in mice expressing the ARQ allele of ovine $\operatorname{PrP}([43])$. Our ongoing studies indicate that human MM1 and MV2 CJD prions can also adapt on the VRQ allele of ovine PrP. This indicates that CJD prions exhibit a retro-zoonotic potential. Reversely, certain scrapie prions could propagate on human $\operatorname{PrP}$ mice [17] and in non-human primates which exhibit similar amino acid sequence as humans [22]. Thus the human to ovine prion transmission barrier may not be absolute. From an evolutionary point of view, these data interrogate on the potential interplay between animal and human prions and their true origin, either spontaneous/sporadic versus infectious. Their fate may not be not as compartmentalized as commonly believed.

\section{Additional file}

Additional file 1: Supplementary Material. (PDF 2698 kb)

Competing interests

The authors declare that they have no competing interests.

Authors' contributions

JC, CC and MD carried out the cell studies, MM carried out the PMCA studies, FR, $\mathrm{LH}, E, H R, H L$ and $V B$ carried out the mouse, biochemical and histopathological studies, IQ, APL and JB carried out the work related to the CID patient, HR participated in the design of the study. VB designed the study and drafted the manuscript. All authors read and approved the final manuscript.

\section{Acknowledgments}

We thank the staff of Animalerie Rongeurs (INRA, Jouy-en-Josas, France) for animal care, Annick Le Dur and Tina Knaple for excellent technical help, Christelle Langevin (INRA, Jouy-en-Josas) for the generation of the P2F plasmid, and Jan Langeveld for the 12B2 anti-PrP monoclonal antibody. This work was partially funded by the Alliance Biosecure Foundation (BoHuToHu project), by the lle de France Region (DIM MALINF) and by the Fondation pour la Recherche Médicale (Equipe FRM DEQ20150331689). 


\section{Author details}

'INRA (Institut National de la Recherche Agronomique), UR892, Virologie Immunologie Moléculaires, F-78350 Jouy-en-Josas, France. ${ }^{2}$ Neurobiology Laboratory, Biochemistry and Molecular Biology Department, Hôpitaux de Lyon, Lyon, France. ${ }^{3}$ University of Lyon 1, CNRS UMR5292, INSERM U1028, BioRan, Lyon, France. ${ }^{4}$ Neurology Department, Centre Hospitalo-Universitaire, Bourg en Bresse, France.

Received: 7 January 2016 Accepted: 26 January 2016 Published online: 05 February 2016

\section{References}

1. Andreoletti $\mathrm{O}$, Orge L, Benestad SL, Beringue $\mathrm{V}$, Litaise $\mathrm{C}$, Simon $\mathrm{S}$, et al. Atypical/Nor98 scrapie infectivity in sheep peripheral tissues. PLoS pathogens. 2011;7, e1001285. doi:10.1371/journal.ppat.1001285.

2. Angers RC, Kang HE, Napier D, Browning S, Seward T, Mathiason C, et al. Prion strain mutation determined by prion protein conformational compatibility and primary structure. Science. 2010;328:1154-8. doi:10.1126/science.1187107.

3. Barria MA, Telling GC, Gambetti P, Mastrianni JA, Soto C. Generation of a new form of human $\operatorname{Pr} P(\mathrm{SC})$ in vitro by interspecies transmission from cervid prions. The Journal of biological chemistry. 2011;286:7490-5. doi:10.1074/jbc.M110.198465.

4. Beringue V, Andreoletti O, Le Dur A, Essalmani R, Vilotte JL, Lacroux C, et al. A bovine prion acquires an epidemic bovine spongiform encephalopathy strainlike phenotype on interspecies transmission. J Neurosci. 2007;27:6965-71. doi:10.1523/JNEUROSCI.0693-07.2007.

5. Beringue $V$, Herzog L, Jaumain E, Reine F, Sibille $P$, Le Dur A, et al. Facilitated cross-species transmission of prions in extraneural tissue. Science. 2012;335: 472-5. doi:10.1126/science.1215659.

6. Beringue V, Herzog L, Reine F, Le Dur A, Casalone C, Vilotte JL, et al. Transmission of atypical bovine prions to mice transgenic for human prion protein. Emerging infectious diseases. 2008;14:1898-901. doi:10.3201/eid1412.080941.

7. Beringue $V$, Le Dur A, Tixador $P$, Reine F, Lepourry L, Perret-Liaudet A, et al. Prominent and persistent extraneural infection in human PrP transgenic mice infected with variant CJD. PloS one. 2008;3, e1419. doi:10.1371/journal. pone.0001419.

8. Beringue V, Vilotte $J$, Laude $H$. Prion agent diversity and species barrier. Veterinary research. 2008;39:47. doi:10.1051/vetres:2008024.

9. Bessen RA, Marsh RF. Biochemical and physical properties of the prion protein from two strains of the transmissible mink encephalopathy agent. Journal of virology. 1992;66:2096-101.

10. Bishop MT, Will RG, Manson JC. Defining sporadic Creutzfeldt-Jakob disease strains and their transmission properties. Proceedings of the National Academy of Sciences of the United States of America. 2010;107:12005-10. doi:10.1073/pnas.1004688107.

11. Brown P, Gibbs Jr CJ, Rodgers-Johnson P, Asher DM, Sulima MP, Bacote A, et al. Human spongiform encephalopathy: the National Institutes of Health series of 300 cases of experimentally transmitted disease. Annals of neurology. 1994;35:513-29. doi:10.1002/ana.410350504.

12. Bruce M, Chree A, McConnell I, Foster J, Pearson G, Fraser H. Transmission of bovine spongiform encephalopathy and scrapie to mice: strain variation and the species barrier. Philos Trans R Soc Lond B Biol Sci. 1994;343:405-11. doi:10.1098/rstb.1994.0036.

13. Bruce ME. Scrapie strain variation and mutation. Br Med Bull. 1993:49:822-38.

14. Bruce ME. TSE strain variation. Br Med Bull. 2003;66:99-108.

15. Bruce ME, Will RG, Ironside JW, McConnell I, Drummond D, Suttie A, et al. Transmissions to mice indicate that 'new variant' CJD is caused by the BSE agent. Nature. 1997;389:498-501. doi:10.1038/39057.

16. Cali I, Castellani R, Alshekhlee A, Cohen Y, Blevins J, Yuan J, et al. Co-existence of scrapie prion protein types 1 and 2 in sporadic Creutzfeldt-Jakob disease: its effect on the phenotype and prion-type characteristics. Brain. 2009;132:2643-58. doi:10.1093/brain/awp196.

17. Cassard H, Torres JM, Lacroux C, Douet JY, Benestad SL, Lantier F, et al. Evidence for zoonotic potential of ovine scrapie prions. Nature communications. 2014:5:5821. doi:10.1038/ncomms6821.

18. Castilla J, Gonzalez-Romero D, Saa P, Morales R, De Castro J, Soto C. Crossing the species barrier by $\operatorname{PrP}(\mathrm{Sc})$ replication in vitro generates unique infectious prions. Cell. 2008;134:757-68. doi:10.1016/j.cell.2008.07.030.
19. Caughey B, Baron GS, Chesebro B, Jeffrey M. Getting a grip on prions: oligomers, amyloids, and pathological membrane interactions. Annu Rev Biochem. 2009;78:177-204. doi:10.1146/annurev.biochem.78.082907.145410.

20. Collinge J. Prion diseases of humans and animals: their causes and molecular basis. Annu Rev Neurosci. 2001;24:519-50. doi:10.1146/annurev. neuro.24.1.519.

21. Collinge J, Clarke AR. A general model of prion strains and their pathogenicity. Science. 2007;318:930-6. doi:10.1126/science.1138718.

22. Comoy EE, Mikol J, Luccantoni-Freire S, Correia E, Lescoutra-Etchegaray N, Durand $V$, et al. Transmission of scrapie prions to primate after an extended silent incubation period. Sci Rep. 2015;5:11573. doi:10.1038/srep11573.

23. Courageot MP, Daude N, Nonno R, Paquet S, Di Bari MA, Le Dur A, et al. A cell line infectible by prion strains from different species. J Gen Virol. 2008; 89:341-7. doi:10.1099/vir.0.83344-0.

24. Feraudet C, Morel N, Simon S, Volland H, Frobert $Y$, Creminon C, et al. Screening of 145 anti-PrP monoclonal antibodies for their capacity to inhibit PrPSc replication in infected cells. J Biol Chem. 2005;280:11247-58. doi:10. 1074/jbc.M407006200.

25. Green KM, Castilla J, Seward TS, Napier DL, Jewell JE, Soto C, et al. Accelerated high fidelity prion amplification within and across prion species barriers. PLoS pathogens. 2008;4, e1000139. doi:10.1371/journal.ppat. 1000139.

26. Halliez S, Reine F, Herzog L, Jaumain E, Haik S, Rezaei H, et al. Accelerated, spleen-based titration of variant Creutzfeldt-Jakob disease infectivity in transgenic mice expressing human prion protein with sensitivity comparable to that of survival time bioassay. Journal of virology. $2014 ; 88$ : 8678-86. doi:10.1128/JVI.01118-14.

27. Hill AF, Joiner S, Linehan J, Desbruslais M, Lantos PL, Collinge J. Speciesbarrier-independent prion replication in apparently resistant species. Proceedings of the National Academy of Sciences of the United States of America. 2000;97:10248-53.

28. Hill AF, Joiner S, Wadsworth JD, Sidle KC, Bell JE, Budka H, et al. Molecular classification of sporadic Creutzfeldt-Jakob disease. Brain. 2003:126:1333-46.

29. Kimberlin $\mathrm{RH}$, Walker $\mathrm{CA}$, Fraser $\mathrm{H}$. The genomic identity of different strains of mouse scrapie is expressed in hamsters and preserved on reisolation in mice. J Gen Virol. 1989;70(Pt 8):2017-25.

30. Kobayashi A, Iwasaki Y, Otsuka H, Yamada M, Yoshida M, Matsuura Y, et al. Deciphering the pathogenesis of sporadic Creutzfeldt-Jakob disease with codon $129 \mathrm{M} / \mathrm{N}$ and type 2 abnormal prion protein. Acta Neuropathol Commun. 2013;1:74. doi:10.1186/2051-5960-1-74.

31. Krasemann S, Groschup MH, Harmeyer S, Hunsmann G, Bodemer W. Generation of monoclonal antibodies against human prion proteins in PrP0/0 mice. Mol Med. 1996;2:725-34

32. Laferriere F, Tixador P, Moudjou M, Chapuis J, Sibille P, Herzog L, et al Quaternary structure of pathological prion protein as a determining factor of strain-specific prion replication dynamics. PLoS Pathog. 2013;9, e1003702. doi:10.1371/journal.ppat.1003702.

33. Langeveld JP, Jacobs JG, Erkens JH, Bossers A, van Zijderveld FG, van Keulen LJ. Rapid and discriminatory diagnosis of scrapie and BSE in retro-pharyngeal lymph nodes of sheep. BMC Vet Res. 2006;2:19. doi:10.1186/1746-6148-2-19.

34. Langevin C, Andreoletti $O$, Le Dur A, Laude H, Beringue V. Marked influence of the route of infection on prion strain apparent phenotype in a scrapie transgenic mouse model. Neurobiol Dis. 2011;41:219-25. doi:10.1016/j.nbd. 2010.09.010.

35. Lasmezas Cl, Fournier JG, Nouvel V, Boe H, Marce D, Lamoury F, et al. Adaptation of the bovine spongiform encephalopathy agent to primates and comparison with Creutzfeldt- Jakob disease: implications for human health. Proceedings of the National Academy of Sciences of the United States of America. 2001:98:4142-7. doi:10.1073/pnas.041490898.

36. Le Dur A, Beringue V, Andreoletti O, Reine F, Lai TL, Baron T, et al. A newly identified type of scrapie agent can naturally infect sheep with resistant PrP genotypes. Proceedings of the National Academy of Sciences of the United States of America. 2005:102:16031-6. doi:10.1073/pnas.0502296102.

37. Li J, Browning S, Mahal SP, Oelschlegel AM, Weissmann C. Darwinian evolution of prions in cell culture. Science. 2010;327:869-72. doi:10.1126/science.1183218.

38. Li J, Mahal SP, Demczyk CA, Weissmann C. Mutability of prions. EMBO Rep. 2011;12:1243-50. doi:10.1038/embor.2011.191.

39. Mahal SP, Browning S, Li J, Suponitsky-Kroyter I, Weissmann C. Transfer of a prion strain to different hosts leads to emergence of strain variants. 
Proceedings of the National Academy of Sciences of the United States of America. 2010;107:22653-8. doi:10.1073/pnas.1013014108.

40. Moda F, Suardi S, Di Fede G, Indaco A, Limido L, Vimercati C, et al. MM2thalamic Creutzfeldt-Jakob disease: neuropathological, biochemical and transmission studies identify a distinctive prion strain. Brain Pathol. 2012;22: 662-9. doi:10.1111/j.1750-3639.2012.00572.x.

41. Moudjou M, Sibille P, Fichet G, Reine F, Chapuis J, Herzog L, et al. Highly infectious prions generated by a single round of microplate-based protein misfolding cyclic amplification. MBio. 2014;5:e00829-00813. doi:10.1128/ mBio.00829-13.

42. Neale MH, Mountjoy SJ, Edwards JC, Vilette D, Laude H, Windl O, et al. Infection of cell lines with experimental and natural ovine scrapie agents. Journal of virology. 2010;84:2444-52. doi:10.1128/JVI.01855-09.

43. Nicot S, Bencsik A, Morignat E, Mestre-Frances N, Perret-Liaudet A, Baron T. Differentiation of prions from L-type BSE versus sporadic Creutzfeldt-Jakob disease. Emerging infectious diseases. 2012;18:2028-31. doi:10.3201/eid1812. 120342.

44. Ojosnegros S, Perales C, Mas A, Domingo E. Quasispecies as a matter of fact: viruses and beyond. Virus Res. 2011;162:203-15. doi:10.1016/j.virusres.2011. 09.018.

45. Parchi P, Giese A, Capellari S, Brown P, Schulz-Schaeffer W, Windl O, et al. Classification of sporadic Creutzfeldt-Jakob disease based on molecular and phenotypic analysis of 300 subjects. Annals of neurology. 1999;46:224-33.

46. Pattison IH, Jones KM. Modification of a strain of mouse-adapted scrapie by passage through rats. Res Vet Sci. 1968;9:408-10.

47. Pattison IH, Millson GC. Scrapie produced experimentally in goats with special reference to the clinical syndrome. J Comp Pathol. 1961;71:101-9.

48. Polymenidou M, Stoeck K, Glatzel M, Vey M, Bellon A, Aguzzi A. Coexistence of multiple PrPSc types in individuals with Creutzfeldt-Jakob disease. Lancet Neurol. 2005:4:805-14. doi:10.1016/S1474-4422(05)70225-8.

49. Prusiner SB. Prions. Proceedings of the National Academy of Sciences of the United States of America. 1998:95:13363-83.

50. Prusiner SB, Cochran SP, Groth DF, Downey DE, Bowman KA, Martinez HM. Measurement of the scrapie agent using an incubation time interval assay. Annals of neurology. 1982;11:353-8. doi:10.1002/ana.410110406.

51. Puoti G, Giaccone G, Rossi G, Canciani B, Bugiani O, Tagliavini F. Sporadic Creutzfeldt-Jakob disease: co-occurrence of different types of $\operatorname{PrP}(\mathrm{SC})$ in the same brain. Neurology. 1999;53:2173-6.

52. Saborio GP, Permanne B, Soto C. Sensitive detection of pathological prion protein by cyclic amplification of protein misfolding. Nature. 2001;411:810-3. doi:10.1038/35081095.

53. Schoch G, Seeger H, Bogousslavsky J, Tolnay M, Janzer RC, Aguzzi A, et al. Analysis of prion strains by PrPSc profiling in sporadic Creutzfeldt-Jakob disease. PLoS Med. 2006;3, e14. doi:10.1371/journal.pmed.0030014.

54. Scott MR, Groth D, Tatzelt J, Torchia M, Tremblay P, DeArmond SJ, et al. Propagation of prion strains through specific conformers of the prion protein. Journal of virology. 1997;71:9032-44.

55. Shikiya RA, Ayers Jl, Schutt CR, Kincaid AE, Bartz JC. Coinfecting prion strains compete for a limiting cellular resource. Journal of virology. 2010;84:5706-14 doi:10.1128/JVI.00243-10.

56. Tixador P, Herzog L, Reine F, Jaumain E, Chapuis J, Le Dur A, et al. The physical relationship between infectivity and prion protein aggregates is strain-dependent. PLoS Pathog. 2010;6, e1000859. doi:10.1371/journal.ppat. 1000859 .

57. Uro-Coste E, Cassard H, Simon S, Lugan S, Bilheude JM, Perret-Liaudet A, et al. Beyond PrP9res) type 1/type 2 dichotomy in Creutzfeldt-Jakob disease. PLoS pathogens. 2008;4, e1000029. doi:10.1371/journal.ppat.1000029.

58. Vilette D, Andreoletti O, Archer F, Madelaine MF, Vilotte JL, Lehmann S, et al. Ex vivo propagation of infectious sheep scrapie agent in heterologous epithelial cells expressing ovine prion protein. Proc Natl Acad Sci U S A. 2001;98:4055-9. doi:10.1073/pnas.061337998.

59. Vilotte IL, Soulier S, Essalmani R, Stinnakre MG, Vaiman D, Lepourry L, et al. Markedly increased susceptibility to natural sheep scrapie of transgenic mice expressing ovine prp. Journal of virology. 2001;75:5977-84. doi:10. 1128/JVI.75.13.5977-5984.2001.

60. Weissmann C. Mutation and selection of prions. PLoS pathogens. 2012;8, e1002582. doi:10.1371/journal.ppat.1002582.

61. Weissmann C, Li J, Mahal SP, Browning S. Prions on the move. EMBO Rep. 2011;12:1109-17. doi:10.1038/embor.2011.192.

62. Will RG. Acquired prion disease: iatrogenic CJD, variant CJD, kuru. Br Med Bull. 2003;66:255-65.

\section{Submit your next manuscript to BioMed Central and we will help you at every step:}

- We accept pre-submission inquiries

- Our selector tool helps you to find the most relevant journal

- We provide round the clock customer support

- Convenient online submission

- Thorough peer review

- Inclusion in PubMed and all major indexing services

- Maximum visibility for your research

Submit your manuscript at www.biomedcentral.com/submit
Biomed Central 